\title{
Mobile Phone Technologies in Coping with the Challenges and Opportunities of CPEC by the Youth of Rural Mountainous Areas of Gilgit-Baltistan, Pakistan
}

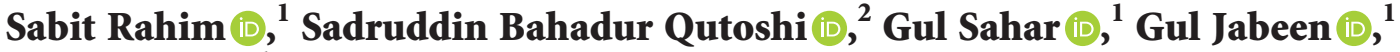 \\ and Imran $\mathbf{A l i}^{1}$ \\ ${ }^{1}$ Department of Computer Sciences, Karakoram International University Gilgit-Baltistan, Gilgit, Pakistan \\ ${ }^{2}$ Department of Educational Development, Karakoram International University Gilgit-Baltistan, Gilgit, Pakistan \\ Correspondence should be addressed to Sabit Rahim; sabit.rahim@kiu.edu.pk
}

Received 19 November 2019; Accepted 24 January 2020; Published 28 February 2020

Academic Editor: Raul Montoliu

Copyright (c) 2020 Sabit Rahim et al. This is an open access article distributed under the Creative Commons Attribution License, which permits unrestricted use, distribution, and reproduction in any medium, provided the original work is properly cited.

\begin{abstract}
The study aims to explore the access of mobile phone, emerging technologies, and use of the mobile phone by the youth of Gilgit-Baltistan (GB), Pakistan, for learning and safety and security purposes. Structured questionnaires were used to collect the data. The descriptive statistics was employed to test the research model. Among the 300 distributed sample size, 272 participants responded back including 133 male and 139 female students of Karakoram International University (KIU) from eight districts of GB as research participants for data collection. Only 1 male and 6 females responded that they do not have their own mobile phone, comprising of $90.6 \%$ response rate. The results show that $97 \%$ of students of rural mountainous areas own a mobile phone. The study contributes valuable findings about the access and positive use of mobile phones for learning and safety and security purposes. The result also shows that the youth of GB have enough skills of mobile phone technologies to cope with the future challenges of China Pakistan Economic Corridor (CPEC) by taking advantages of China Pakistan Information Corridor (CPIC is a fiber optics cable laid down from the China border to Islamabad Pakistan for the purpose of providing the fast internet facility including 5G). This is the baseline survey and future study will be based on this survey.
\end{abstract}

\section{Introduction}

Mobile phones have been identified as catalyst due to the key features such as portability, real time communication, and access to information [1]. It has an effect on the way that individuals play their different roles in society [2]. For example, youth in GB use mobile phone as a powerful technological device for multiple purposes in their lives. Therefore, mobile phone has both positive and negative consequences for their lives. After getting exposed to this technology, in a very short span of time, it has changed the way in which individuals are interacting with each other [3].

The mobile, as a powerful gadget, has become the necessary piece of technology in the life of youth. Thus, the youth is now playing a vital role in every walk of life in this era of technological advancement. For instance, students can use their phone for learning purposes [4]. They need mobile for access to and share of information such as a portal for communication and short messaging $[5,6]$. Moreover, it is needed for entertainment and access to social networks because it has become the manifestation of digital age [7].

In fact, the mobile phone has turned from a technological tool to an educational, economic, and social tool. One of the key attributes of mobile phone technology is its portability for real time information sharing and contact with others. Using mobile phone rather than the fixed telephone line is a way to keep in touch with family, friends, colleagues, and business associates [8]. Moreover, it gives the facility to do online transactions $[9,10]$. Mobile phone has become the social phenomena all over the world especially in least developed countries like Africa, Pakistan, India, Bangladesh, and Iran [11]. However, mobile phone has both positive and negative impacts depending on its usage, because it is enveloping new communication technology among youth [12]. 
The usage of mobile phone was limited to big cities few years ago. Nowadays, it is rapidly penetrating the rural areas including mountainous regions such as GB. Thus, this technology to a great extent has filled the gaps between developed and underdeveloped areas. Mobile phone is one of the most common technological devices with almost $31 \%$ of the world's population using it [13].

In the context of Pakistan, in general and in GB in particular, before the emergence of mobile phone, there was a fixed telephone line (i.e. land line) for just communication purposes. At the time of landline technology, majority of the people of GB did not show their interest to adopt the fixed telephone line. But, later in 2007, mobile phone was introduced in GB and everyone started to use mobile phone because of its portability, privacy, and many other features. Mobile phone has become the most accessible and inexpensive technology for the people of GB, especially youth.

The above mentioned technological tools have exerted significant social, economic, educational, and psychological impacts in the society even in these mountainous rural areas of GB, especially in the context of the Pakistan China Economic corridor (CPEC). When CPEC has some key opportunities such as regional connectivity, infrastructure, energy, agriculture development, poverty alleviation, education, health, and people-to-people contact, at the same time, there are also some challenges that will be faced by the people of Pakistan, especially GB such as skilled workforce on the emerging technologies for business, education, transportation, energy, agriculture, heath, and infrastructure as China is fastest adopter of emerging technologies.

So, this study focuses to investigate to what extent the youth has access to and use of mobile phone for education and security purpose by using the facilities of CPIC, a fiber optics from China to Pakistan. However, there is a dearth of research studies regarding impact of mobile phone in teenagers, youth, and society in Pakistan, especially in GB in context of CPEC. To fill this gap in the context, we conducted this research on access to mobile phone and its usage among the teenagers and youth of GB.

\section{Literature Review}

2.1. Impact of Mobile Phone. According to authors [2], initially, the mobile phone was used for communication only. Its extensive use all over the world and its exploitation increases day by day [6]. In current time, it is being used for multiple purposes [14], such as web browsing, accessing online materials, entertainment, education, social relationship, security, and business activities [15]. The mobile phone was introduced primarily to connect people thousands of miles away from each other [16]. This technology has become portable in nature and always contactable or steady for communication [13, 17, 18]. According to [19], the mobile phone has altered the concept of communication and enhanced situation of health, disaster, education, security activities, social interactions, making any decision, and traveling.

The mobile phone has introduced a wide range of innovative potentials for social networks [15], media usage and productivity, information sharing, political activities, security, safety, and learning [11]. Innovative things have a tendency to create anxieties among aged people; the rapid growth in adoption and advancement in mobile phone technology brought challenges and difficulties for the elder users as compared to younger users [20]. In the same line, the authors in [21] listed the mobile phone users in groups and study their behaviors towards mobile phones such as cost consciousness, safety conscious, mobile dependent users, sophisticated users, and practical user. One of the criticisms on mobile phones is that it deteriorates present norms of social limitations, but it is a technology that releases the user from the restrictions of time and space [22].

People use mobile phones not only for business purposes but also for entertainment, security, and education [23]. The mobile phone can empower females to do small businesses and provide a sense of security and learning environment, as well as eliminate gapes between gender income variations [24]. From a study in rural Bangladesh, it is observed that 74.2\% correspondents believe that mobile phones have decreased the cost of communication, while $85 \%$ believe that the mobile phone has cut the overall communication expenses and $79.2 \%$ think that it lowers the travelling cost also $[25,26]$. It means that the mobile phone can play a vital role in education, safety and security, industries, and mobile finance [27].

The authors in [28] said that students use mobile technology basically for social and entertainment purposes. $90 \%$ students use mobile phones for texting messages, and $86 \%$ students send and receive or check emails. The youth share information, get knowledge, and learn by internetenabled mobiles $[29,30]$, and it is an essential component for college and university students [31]. The mobile phone has been used as a symbol of identity that helps the youth to be independent in their interactions within and outside the family and want to reinforce their identity [32]. Attitude and behaviors of teenagers towards the mobile phone is notable. Participants, mostly female, stated that they feel free and safe because they are able to contact their family and relatives in case of emergency at any time from any location.

According to [33], a large number of youth is dependent on the mobile phone to contact friends and to use social network sites like Facebook, LinkedIn, and Twitter, consulting for lectures, getting information, and using internet [2]. Its contribution towards quality learning is enormous for teenagers and youth [34].

In [35] authors stated that ringing of the mobile phone during class affects the whole learning environment. It is also used for cheating purposes in exams which may affect the students' learning ability [36]. The students of GB get advantage from their mobile phones by mutual activities through SMS, listening lectures, sharing information, and educational applications (like mobile dictionary) [37]. It has also influenced various aspects of daily lives of GB youth. Students easily share thoughts and information among each other $[38,39]$. Students use mobile phone devices to upload and post their academic data to course websites, and each student gets access to their course $[40,41]$. 
2.2. CPEC Opportunities and Challenges. The China Pakistan Economic Corridor is a game changer for the whole region. This great game was initially started to link with the resource-rich central Asia, but later on, it has been expanded throughout Asia. It also connects the Middle East, Southeast Asia, and most important strategically south Asian countries. In context of Pakistan, CPEC has many opportunities and also challenges. The proper addressing of these opportunities and challenges on time is the most important and daunting task for Pakistan. The following sections mention the opportunities and challenges of CPEC.

\subsubsection{CPEC Opportunities}

(i) Infrastructure and energy production [42]

(ii) Roads and railways networks [43]

(iii) Expansion and development of the Gwadar port [44]

(iv) Establishment of special economic zones (SEZs) [43]

(v) Technical training institutes are also part of the CPEC [42]

\subsubsection{Challenges for CPEC}

(i) Security threats for CPEC in Pakistan [45]

(ii) Indian reservation about CPEC [46]

(iii) Political controversies about CPEC in Pakistan [47]

(iv) Trained workforce in emerging technologies [47]

(v) Access quality education using emerging technologies

(vi) Proper utilization of facility of the China Pakistan Information Corridor (CPIC) [48]

Our basic work is focused is on the Pakistan-China Fiber Optic Project, the authors suggest the name of this project as the China Pakistan Information Corridor (CPIC), which is an 820 kilometer long optical fiber cable that has been laid down between the Khunjerab Pass on the China-Pakistan border and the city of Islamabad. This is also one of the parts of CPEC projects. Its cost $\$ 44$ million. The project's groundbreaking took place on May 19, 2016, in the city of Gilgit, and the project will bring $3 \mathrm{G}$ and $4 \mathrm{G}$ connectivity to the GB region [48]. The CPIC project will connect the Transit Europe-Asia Terrestrial Cable Network with Pakistan, which currently transmits its telecom and internet traffic through four undersea fiber optic cables, with another three undersea fiber optic cables under construction. 466.54 kilometers of the route is located in GB, while $287.66 \mathrm{ki}-$ lometers is laid in Khyber Pakhtunkhwa province, 47.56 kilometers is in Punjab province, and 18.2 kilometers in Islamabad Capital Territory.

The project has been completed and inaugurated in July 2018 [49]. The project is owned by the military-run Special Communication Organization (SCO), and its engineering, procurement, and construction (EPC) contractor is Huawei. The CPIC will provide fast internet, phone calls, and $3 \mathrm{G}$ and
$4 \mathrm{G}$ facilities for GB and even for the whole of Pakistan. It will also provide a facility for high-speed internet of $5 \mathrm{G}$.

\section{Objectives of the Study}

The objectives of this research are to

(i) Explore to what extent the emerging technologies are being used by the youth of GB

(ii) Investigate how the youth of GB access and use the mobile phone

(iii) Know how the mobile phone helps youth to address future challenges and opportunities related to CPEC

\section{Methodology}

4.1. Data Collection. The data were collected through structured questionnaires. The questionnaires were personally distributed among both male and female youth students belonging to eight districts of GB.

4.2. Area and Sample. The survey was conducted in GB from where the CPEC route is going through. The sample of survey respondents comprises youth of age 16 to 30 years. The survey was conducted among both male and female youth. It collected demographic information like name, age, gender, district, income, technology equipment, and access to mobile phone. Among 300 respondents, 272 participants responded back comprising $90.6 \%$ response rate. $48.9 \%$ male and $51.1 \%$ female respondents participated in the study (133 male and 139 female).

4.3. Scales and Measurements. The research study consists of three main objectives. The first objective is to collect personal information like age, gender, households' access of emerging technologies, and access to mobile phone by the youth of GB. The second objective comprises the use of mobile phone by the youth of GB in education and safety and security purposes. The last objective is to collect literature about the challenges and opportunities related to CPEC. The descriptive statistics was employed to test the research model. In order to identify these, the respondents were asked to indicate their agreement for each statement ranging from $1=$ strongly agree to $5=$ strongly disagree, and for some questions, they were asked to answer Yes or No.

\section{Findings}

5.1. Demographic Information. This section addresses the first objective of the study. Table 1 shows the details about the demographic such as age, gender, and access to emerging technologies and mobile phone as a necessary piece of technology. In this study, $18 \%$ of the sample belongs to the age group of less than 20 . Selection of this age group is made to see the mobile phone usage level among the teenagers of the GB. The large number of sample comprised of respondents within age range of $20-25$ is $76.5 \%$. This age group is selected to observe the mobile phone usage level 
TAвLE 1: Frequency of age, gender, and access to emerging technologies and mobile phones or a necessary piece of technology.

\begin{tabular}{|c|c|c|}
\hline Variables & Frequency & Percent \\
\hline \multicolumn{3}{|l|}{ Age (in years) } \\
\hline Less than 20 & 49 & 18.0 \\
\hline $20-25$ & 208 & 76.5 \\
\hline $25-30$ & 13 & 4.8 \\
\hline Above 30 & 2 & 0.7 \\
\hline Total & 272 & 100.0 \\
\hline \multicolumn{3}{|l|}{ Gender } \\
\hline Male & 133 & 48.9 \\
\hline Female & 139 & 51.1 \\
\hline Total & 272 & 100.0 \\
\hline \multicolumn{3}{|l|}{ Access to technologies at household level } \\
\hline Telephone & 9 & 3.3 \\
\hline Computer & 14 & 5.1 \\
\hline TV & 31 & 11.4 \\
\hline Laptop & 11 & 4.0 \\
\hline Internet devices & 1 & 0.4 \\
\hline Telephone and computer & 1 & 0.4 \\
\hline Telephone and TV & 5 & 1.8 \\
\hline Telephone and laptop & 6 & 2.2 \\
\hline Computer and TV & 26 & 9.6 \\
\hline Computer and laptop & 7 & 2.6 \\
\hline Computer and internet devices & 1 & 0.4 \\
\hline TV and laptop & 21 & 7.7 \\
\hline Telephone, computer and TV & 9 & 3.3 \\
\hline Telephone, TV and laptop & 7 & 2.6 \\
\hline Computer, TV and laptop & 39 & 14.3 \\
\hline $\mathrm{TV}$, laptop and internet devices & 1 & 0.4 \\
\hline Telephone, computer, TV and laptop & 32 & 11.8 \\
\hline Computer, TV, laptop, and internet devices & 4 & 1.5 \\
\hline Telephone, computer, TV, laptop, and internet devices & 38 & 14.0 \\
\hline Telephone, computer and laptop & 4 & 1.5 \\
\hline Computer, TV, and internet devices & 2 & 0.7 \\
\hline No response & 3 & 1.1 \\
\hline Total & 272 & 100.0 \\
\hline \multicolumn{3}{|l|}{ Mobile phones are a necessary piece of technology } \\
\hline Yes & 258 & 94.9 \\
\hline No & 8 & 2.9 \\
\hline No response & 6 & 2.2 \\
\hline Total & 272 & 100.0 \\
\hline
\end{tabular}

among the youth of the GB. There are only $4.8 \%$ samples within the age range of $25-30$ and $0.7 \%$ samples within the age group of more than 30 years.

The survey was conducted in all the 16 departments of Karakoram International University (KIU) GB. The following departments' students who were from rural areas participated in the survey; computer science $23.9 \%$, management science $8.5 \%$, economics $5.9 \%$, education $9.2 \%$, food and agriculture $1.1 \%$, math $7.0 \%$, international relation $2.9 \%$, modern language $7.4 \%$, behavioral sciences $3.3 \%$, environmental science $2.6 \%$, biology $4.8 \%$, chemistry $2.9 \%$, physics $1.5 \%$, earth science $4.4 \%$, statistic $1.5 \%$, mass communication $3.3 \%$.

The result shows that the respondents belong to the following districts of Gilgit-Baltistan such as district Ghizer $18.4 \%$, Gilgit 21.7\%, Hunza 16.9\%, Nagar 8.1\%, Skardu 13.6\%, Ghanche 3.7\%, Astore 6.6\%, and Diamer $4.4 \%$ and other means down country like Punjab, KPK, Sindh, and
Baluchistan 4.4\%. Remaining 2.2\% did not mention their district. The respondents were asked about access to technologies at the household level other than the mobile phone. We found that majority of the people of rural remotes areas of GB own a computer, TV, and laptop. $14 \%$ said that they own all these emerging technologies at home such as telephone, computer, TV, laptop, and internet devices. Majority of the participants stated that mobile phones are a necessary piece of technology in today's world, while only $2.9 \%$ opposed it. $2.2 \%$ respondents did not mention their answer, as shown in Table 1.

There is no significant difference in access to mobile phone in all districts of GB. The female are also participating to own a mobile phone at the same ratio as the male such as 132 male participated and only 1 male said that he does not have mobile phone. Similarly, 133 female participated and only 6 female said that they do not have a mobile phone. So, the result shows that females are almost at the same ratio as 
male participants. The result shown in Table 2 summarizes gender-wise access to mobile phone at the district level.

5.2. Access to Mobile Phone. $97.43 \%$ students responded that they have a mobile phone, both male and female and $40.07 \%$ responded that they have a simple mobile phone, $34.19 \%$ responded that they have a smart phone, $22.79 \%$ responded that they have both smart and simple mobile phones, and remaining $2.94 \%$ did not respond to the questions. Those who did not own a mobile phone mentioned the following reasons for not having it. $0.4 \%$ said due to cost, $0.7 \%$ said that their family does not allow, and $0.7 \%$ said that they do not own due to the concept of miss use of mobile phones. As compared to respondents having mobile phone, those who do not own a mobile phone are negligible in quantity. The result in Table 3 shows that the youth of GB avail this emerging technology for their daily life usage.

As far as spending of money on mobile phone is concerned, $27.6 \%$ respondents said that they spent less than 100 rupees (rupees means Pakistani currency) in a month, 39\% said that they spend 100 to 200 rupees, $23.9 \%$ said that they spend $200-500$ rupees, $7.4 \%$ said that they spend more than 500 rupees per month, and only $2.2 \%$ did not respond to the question. Those who spend more than 200 rupees mentioned that they use Internet packages to access various materials and applications.

A positive response has been recorded in the question of "mobile phone is a necessary piece of technology in today's world". $94.9 \%$ responded in the favor of the question and only 2.9 responded against, and $2.2 \%$ respondents did not respond to the question. It means that the technology, especially the mobile phone, is one the important tools in modern era, and students of rural mountainous areas are taking full benefits of the mobile phone. The respondents reported that the use of the mobile phone for safety and security purpose is very significant in their lives. As, $83.1 \%$ respondents replied that when they do not have a mobile phone, they feel disconnected from family, friends, and colleagues. $79.4 \%$ students responded that they always leave their mobile phone switch on, and $18.4 \%$ said that they switch off their mobile phone during Namaz, classroom time, and at night.

5.3. Use of Mobile Phone for Learning Purpose. This section addresses the second objective of the study. The result shows that $80.8 \%$ respondents, both male and female, said that the mobile phone has increased their learning skills and $17.3 \%$ disagreed with the statement. 36\% respondents strongly agree that they use the mobile phone to download educational apps, $30.1 \%$ agreed, $14.7 \%$ somehow agreed, and $7.4 \%$ and $9.2 \%$ strongly disagreed and disagreed, respectively. $28.3 \%$ respondents strongly agreed that they use the mobile phone for listening lectures, 38.2\% agreed, $18 \%$ somehow agreed, and only $8.1 \%$ disagreed and $4.8 \%$ strongly disagreed with the statement. The results show that the students of rural mountainous areas positively use the mobile phone for learning purpose which has increased their learning. While responding to the question related to the use of the mobile
TABLE 2: Gender-wise access to mobile phone at the district level.

\begin{tabular}{|c|c|c|c|c|c|}
\hline \multirow[t]{2}{*}{ Respondents' } & ict & & $\begin{array}{c}\text { Do } \\
\text { ha } \\
\text { yo } \\
\text { ov } \\
\text { mo } \\
\text { pho }\end{array}$ & $\begin{array}{l}\text { jou } \\
\text { je } \\
\text { dr } \\
\text { n } \\
\text { ile } \\
\text { ne? }\end{array}$ & \multirow[t]{2}{*}{ Total } \\
\hline & & & Yes & No & \\
\hline \multirow{3}{*}{ Ghizer } & \multirow{3}{*}{$\begin{array}{c}\text { Respondents' gender } \\
\text { Total }\end{array}$} & Male & 21 & 1 & 22 \\
\hline & & Female & 27 & 1 & 28 \\
\hline & & & 48 & 2 & 50 \\
\hline \multirow{3}{*}{ Gilgit } & \multirow{3}{*}{$\begin{array}{c}\text { Respondents' gender } \\
\text { Total }\end{array}$} & Male & 34 & 0 & 34 \\
\hline & & Female & 23 & 2 & 25 \\
\hline & & & 57 & 2 & 59 \\
\hline \multirow{3}{*}{ Hunza } & \multirow{3}{*}{$\begin{array}{c}\text { Respondents' gender } \\
\text { Total }\end{array}$} & Male & 13 & 0 & 13 \\
\hline & & Female & 31 & 2 & 33 \\
\hline & & & 44 & 2 & 46 \\
\hline \multirow{3}{*}{ Nagar } & \multirow{3}{*}{$\begin{array}{c}\text { Respondents' gender } \\
\text { Total }\end{array}$} & Male & 11 & & 11 \\
\hline & & Female & 11 & & 11 \\
\hline & & & 22 & & 22 \\
\hline \multirow{3}{*}{ Skardu } & \multirow{3}{*}{$\begin{array}{c}\text { Respondents' gender } \\
\text { Total }\end{array}$} & Male & 18 & 0 & 18 \\
\hline & & Female & 18 & 1 & 19 \\
\hline & & & 36 & 1 & 37 \\
\hline \multirow{3}{*}{ Ghanche } & \multirow{3}{*}{$\begin{array}{c}\text { Respondents' gender } \\
\text { Total }\end{array}$} & Male & 4 & & 4 \\
\hline & & Female & 6 & & 6 \\
\hline & & & 10 & & 10 \\
\hline \multirow{3}{*}{ Astore } & \multirow{3}{*}{$\begin{array}{c}\text { Respondents' gender } \\
\text { Total }\end{array}$} & Male & 8 & & 8 \\
\hline & & Female & 10 & & 10 \\
\hline & & & 18 & & 18 \\
\hline \multirow{3}{*}{ Diamer } & \multirow{3}{*}{$\begin{array}{c}\text { Respondents' gender } \\
\text { Total }\end{array}$} & Male & 11 & & 11 \\
\hline & & Female & 1 & & 1 \\
\hline & & & 12 & & 12 \\
\hline \multirow{3}{*}{ Other } & \multirow{3}{*}{$\begin{array}{c}\text { Respondents' gender } \\
\text { Total }\end{array}$} & Male & 9 & & 9 \\
\hline & & Female & 3 & & 3 \\
\hline & & & 12 & & 12 \\
\hline \multirow{3}{*}{ No response } & \multirow{3}{*}{$\begin{array}{c}\text { Respondents' gender } \\
\text { Total }\end{array}$} & Male & 3 & & 3 \\
\hline & & Female & 3 & & 3 \\
\hline & & & 6 & & 6 \\
\hline
\end{tabular}

phone for consulting with other students and lecturers, $38.2 \%$ students strongly agreed, 36\% agreed, $13.2 \%$ agreed somehow, $8.1 \%$ disagreed, and $1.8 \%$ strongly disagreed. The results in Table 4 show that the mobile phone fully contributes in the learning process of University students, if and only if they will use it in positive ways. The positive utilization of the mobile phone may prepare the young people of GB to face the challenges of CPEC and benefit from opportunities of China Pakistan Information Corridor in effective ways.

5.4. Use of Mobile Phone for Safety and Security Purpose. In response to the question "use of the mobile phone for safety and security purpose" such as parents use it to know whereabouts of their sons and daughters. The majority of the respondents stated that when they have mobile phone, their parents feel more comfortable by contacting them time to time to know about their safety and security and worried less about them. Little percentage of respondents, i.e., $11.7 \%$ 
TABLE 3: Access to mobile phone and usage.

\begin{tabular}{|c|c|c|}
\hline & Frequency & Percent \\
\hline \multicolumn{3}{|l|}{ Do you have your own mobile phone? } \\
\hline Yes & 265 & 97.43 \\
\hline No & 7 & 2.57 \\
\hline \multicolumn{3}{|l|}{ If yes, which kind of mobile phone do you have? } \\
\hline Simple mobile phone & 109 & 40.07 \\
\hline Smart mobile phone & 93 & 34.19 \\
\hline Both simple and smart mobile phone & 62 & 22.79 \\
\hline No response & 8 & 2.94 \\
\hline \multicolumn{3}{|c|}{ If no, what are the reasons for you not having a mobile phone? } \\
\hline Cost of the mobile phone & 1 & 0.37 \\
\hline Family does not allow to use a mobile phone & 2 & 0.74 \\
\hline Concept of miss use of the mobile phone & 2 & 0.74 \\
\hline No response & 267 & 98.16 \\
\hline \multicolumn{3}{|c|}{ Spending on the mobile phone (balance card, easy load) per month in rupees. } \\
\hline Less than 100 & 75 & 27.57 \\
\hline $100-200$ & 106 & 38.97 \\
\hline $200-500$ & 65 & 23.90 \\
\hline Above 500 & 20 & 7.35 \\
\hline No response & 6 & 2.21 \\
\hline \multicolumn{3}{|c|}{ When I do not have a mobile phone, I feel disconnected } \\
\hline Yes & 226 & 83.09 \\
\hline No & 40 & 14.71 \\
\hline No response & 6 & 2.21 \\
\hline \multicolumn{3}{|l|}{ I always leave my mobile phone on } \\
\hline Yes & 216 & 79.41 \\
\hline No & 50 & 18.38 \\
\hline No response & 6 & 2.21 \\
\hline Total & 272 & 100 \\
\hline
\end{tabular}

TABLE 4: Use of the mobile phone for learning and safety and security purpose.

\begin{tabular}{|c|c|c|c|c|c|c|}
\hline & \multicolumn{6}{|c|}{ Percent } \\
\hline & $\begin{array}{r}\text { Strongly } \\
\text { disagree }\end{array}$ & Disagree & $\begin{array}{l}\text { Somehow } \\
\text { agree }\end{array}$ & Agree & $\begin{array}{c}\text { Strongly } \\
\text { agree }\end{array}$ & $\begin{array}{l}\text { No } \\
\text { response }\end{array}$ \\
\hline \multicolumn{7}{|l|}{ Use of the mobile phone for learning purpose } \\
\hline I download educational apps using the mobile phone & 7.35 & 9.19 & 14.71 & 30.15 & 36.03 & 2.57 \\
\hline I listen audio and video lectures using the mobile phone & 4.78 & 8.09 & 18.01 & 38.24 & 28.31 & 2.57 \\
\hline $\begin{array}{l}\text { I use the mobile phone for consulting with other } \\
\text { students and lecturers }\end{array}$ & 1.84 & 8.09 & 13.24 & 36.03 & 38.24 & 2.57 \\
\hline \multicolumn{7}{|l|}{ Use of the mobile phone for safety and security purpose } \\
\hline Having a mobile phone, I feel safer & 4.78 & 14.71 & 21.69 & 35.29 & 21.32 & 2.21 \\
\hline Having a mobile phone, parents worry less about me & 4.04 & 7.72 & 13.60 & 47.79 & 24.63 & 2.21 \\
\hline I use a mobile phone to contact in emergency & 2.57 & 2.94 & 8.46 & 40.07 & 43.75 & 2.21 \\
\hline
\end{tabular}

disagreed, and $13.6 \%$ were in the range of somehow agreement as shown in Table 4.

5.5. Opportunities of CPIC. The current literature and our findings show that mobile phone has great impact on the daily lives of teenagers and youths of rural remote areas of GB. It has turned challenges (access of resources anytime anywhere) into opportunities. The CPIC will provide a high-speed path for internet and 3G, 4G, and 5G (5G will launch in 2020). The teenagers and youths of GB will get benefited from the mobile phone on the aspects of learning, e.g., social learning, cooperative group learning, and constructivist interaction because of its portability, connectivity, convenience, expediency, immediacy, accessibility, individuality, and interactivity. Mobile phone offers anytime anywhere access to web materials. The challenges of security threats for Pakistan can be resolved by providing smart city system because the CPIC will provide fast communication path. To access high-quality education, open educational resources and MOOC services will be provided online which can be accessed via a mobile phone. A more detail recommendation has been mentioned in section 6 . 


\section{Recommendations}

6.1. Educational Network among Chinese and Pakistani Universities. Mobile phone including other technologies can provide a collaborative virtual learning environment [50] from Chinese as well as from Pakistani Universities in regular degree programs and also in skill development courses $[51,52]$ such as learn freelancing, English language, Chinese language, computer skills, telecommunication and networking, alternate energy source (solar, hydro power, and wind), custom clearing, goods forwarding, transport management, tourism management, and retail-housing systems, and research and development [53].

6.2. Social Media and Cultural Exchange. Using mobile phone technologies along with other technologies, there is a need to tailor social media applications [54] and provide forums for youth of both countries (China and Pakistan) to make them understand their respective cultural norms. Custom-developed mobile apps can be used for teaching and learning in this context. This will provide an effective learning environment for youth of both countries regarding culture and will let them learn from the experiences [55], because the youth are the largest group that use mobile phone in both China and Pakistan.

6.3. Job Advertisement Regarding CPEC and CPIC. Mobile phone application can help the authorities who may develop such forums that offer awareness and firsthand information about career and economic opportunities regarding the China Pakistan Economic corridor. The China Pakistan Information Corridor (CPIC) will be used to provide the facilities and post the information on the web portal, and the youth will get alert according to their requirement. The job seekers can apply via the job portal and employer will train as per their organization's requirement of fresh candidates and placement should be ensured after training.

6.4. Limitation and Future Direction of Research. This study provides some significant empirical evidence regarding use of mobile phone by university students in learning, safety, and security purposes [56]. There are some limitations such as this study only focused on the usage of mobile phones among young people [53], but in the reality, there are other people like professionals and businessmen who also use similar devices [57], so future researchers can explore other users to know about their purpose of using a mobile phone. Another point is that there are many other devices such as iPads, Tablets, PCs, palm devices, and laptops. These devices can also play a vital role in the context of education, business, and social relation. In future, the research may focus the use of mobile phone in the business context in young people as well as professional and businessmen both male and females of GB. The research will also be focused on psychological issues and negative impact of mobile phone usage among the youth of GB.

\section{Discussion}

The study shows that mobile phone has become a fundamental tool of technology that is needed in the lives of youth of GB. It keeps the users up to date with the world and helps them to remain connected with their family members and friends using less amount of money. In this study, all the respondents, especially females, agreed that owning a mobile phone, they feel safer and have a sense of safety and security. The mobile phone is not only the means of communication but also the media for entertainment and access to digital learning materials [19]. The mobile phone has given the youth with new and thrilling ways to interact with the people who are living abroad.

The university students of rural mountainous areas are very much motivated to use mobile phone for learning purposes. They also use it in other positive ways such as for safety [16]. The usage of mobile phone is varying from person-to-person. Most of the people use mobile phone as a tool for business activities, social activities, and online transaction. This emerging tool has also changed the lifestyle of youth of GB. The extensive use of mobile phone by university students for learning purpose is one of the positive signs to cope up with the forthcoming challenges and availing opportunities of the China Pakistan Economic Corridor [58]. The outcomes of the study have tremendous implications for not only the users of mobile phone technology in the context of GB but also beyond the borders with similar context elsewhere in the world.

\section{Conclusion}

The study shows that the youth of Gilgit-Baltistan province of Pakistan are fully enjoying the benefits of mobile phone technology as one of the $21^{\text {st }}$ century great inventions. One of the most interesting findings of the study shows that the youth here in GB use this emerging technology in a very positive manner. On the basis of these findings, one can infer that mobile phone technologies have greater impact on the youth of mountainous rural areas of GB. For example, 97\% youth own a mobile phone, and $80.8 \%$ students, both male and female, reported that mobile phone has increased their learning skills. $21 \%$ students strongly agreed that when they own a mobile, they fell safe and secure and their parents feel comfortable by contacting them from time to time. The result also shows that the youth of GB have developed their basic skills in these technologies to cope with challenges of CPEC. On the basis of these finding, we can expect that, in future, the youth will effectively use the China Pakistan Information corridor (EPIC) for fast and reliable internet services to access online teaching and learning materials, skill development courses, and job-related posts and material by using the mobile phone.

Finally, it is concluded that positive impacts of mobile phone are more than its negative impacts in the lives of the youth of GB (both male and female). It is an important piece of technology which can be used to take advantages as emerging technology not for antisocial activities [59]. 


\section{Data Availability}

The data used to support the findings of this study are included within the article. We cannot provide SPSS file of the data because the file consists of some other data which are not published yet. If necessary, the portion of data can be provided upon request.

\section{Conflicts of Interest}

All the authors declare that there are no conflicts of interest.

\section{References}

[1] A. Rhema and E. Sztendur, "Using a mobile phone to support learning: experiences of engineering students in Libya," in Proceedings of the Informing Science and Information Technology Education Conference, pp. 215-238, Tampa, FL, USA, June 2013

[2] S. Chatterjee, "A sociological outlook of mobile phone use in society," International Journal of Interdisciplinary and Multidisciplinary Studies, vol. 1, pp. 55-63, 2014.

[3] A. K. Przybylski and N. Weinstein, "Can you connect with me now? how the presence of mobile communication technology influences face-to-face conversation quality," Journal of Social and Personal Relationships, vol. 30, no. 3, pp. 237-246, 2013.

[4] J. H. Kuznekoff, S. Munz, and S. Titsworth, "Mobile phones in the classroom: examining the effects of texting, twitter, and message content on student learning," Communication Education, vol. 64, no. 3, pp. 344-365, 2015.

[5] M. R. Power and D. Power, "Everyone here speaks TXT: deaf people using SMS in Australia and the rest of the world," Journal of Deaf Studies and Deaf Education, vol. 9, no. 3, pp. 333-343, 2004.

[6] H. Cole-Lewis and T. Kershaw, "Text messaging as a tool for behavior change in disease prevention and management," Epidemiologic Reviews, vol. 32, no. 1, pp. 56-69, 2010.

[7] C. Barrie, J. Bartkowski, and T. Haverda, "The digital divide among parents and their emerging adult children: intergenerational accounts of technologically assisted family communication," Social Sciences, vol. 8, no. 3, p. 83, 2019.

[8] S. N. Zulkefly and R. Baharudin, "Mobile phone use amongst students in a university in Malaysia: its correlates and relationship to psychological health," European Journal of Scientific Research, vol. 37, pp. 206-218, 2009.

[9] M. Wazid, S. Zeadally, and A. K. Das, "Mobile banking: evolution and threats: malware threats and security solutions," IEEE Consumer Electronics Magazine, vol. 8, no. 2, pp. 56-60, 2019.

[10] J. U. Sheetal, J. Upadhyay, D. N. Purohit, and A. Vyas, "Increase in number of online services and payments through mobile applications post demonetization," Advances in Management, vol. 12, no. 1, pp. 34-38, 2019.

[11] T. Kreutzer, "Assessing cell phone usage in a south African township school," International Journal of Education and Development Using Information and Communication Technology, vol. 5, no. 5, pp. 43-57, 2009.

[12] H.-L. Chou and C. Chou, "A quantitative analysis of factors related to Taiwan teenagers' smartphone addiction tendency using a random sample of parent-child dyads," Computers in Human Behavior, vol. 99, pp. 335-344, 2019.

[13] S. Chakraborty, Mobile Phone Usage Patterns Amongst University Students: A Comparative Study between India and USA, University of North Carolina, Chapel Hill, NC, USA, 2006.
[14] H. H. Yang, "New world, new learning: trends and issues of e-learning," Procedia-Social and Behavioral Sciences, vol. 77, pp. 429-442, 2013.

[15] L. Fortunati, “The mobile phone: towards new categories and social relations1," Information, Communication \& Society, vol. 5, no. 4, pp. 513-528, 2002.

[16] I. Ahmed and T. F. Qazi, "Mobile phone adoption \& consumption patterns of university students in Pakistan," International Journal of Business and Social Science, vol. 2, 2011.

[17] R. Wei and V.-H. Lo, "Staying connected while on the move," New Media \& Society, vol. 8, no. 1, pp. 53-72, 2006.

[18] P. Matanhelia, Mobile Phone Use by Young Adults in India: A Case Study (Unpublished Doctoral Dissertation), University of Maryland, College Park, MD, USA, 2010.

[19] S. Malik, I. S. Chaudhry, and Q. Abbas, "Socio-economic impact of cellular phones growth in Pakistan: an empirical analysis," Pakistan Journal of Social Sciences (PJSS), vol. 29, no. 1, pp. 23-37, 2009.

[20] T. Page, "Touchscreen mobile devices and older adults: a usability study," International Journal of Human Factors and Ergonomics, vol. 3, no. 1, pp. 65-85, 2014.

[21] K. Aoki and E. J. Downes, "An analysis of young people's use of and attitudes toward cell phones," Telematics and Informatics, vol. 20, no. 4, pp. 349-364, 2003.

[22] M. Ito and D. Okabe, "Technosocial situations: emergent structurings of mobile email use," in Personal, Portable, Pedestrian: Mobile Phones in Japanese Life, vol. 20, pp. 257-273, MIT Press, Cambridge, MA, USA, 2005.

[23] M. Conci, F. Pianesi, and M. Zancanaro, "Useful, social and enjoyable: mobile phone adoption by older people," in $\mathrm{Hu}$ man-Computer Interaction, pp. 63-76, Springer, Berlin, Germany, 2009.

[24] S. A. Asongu, "How has mobile phone penetration stimulated financial development in Africa?," Journal of African Business, vol. 14, no. 1, pp. 7-18, 2013.

[25] A. K. Bairagi, T. Roy, and A. Polin, "Socio-economic impacts of mobile phone in rural Bangladesh: a case study in Batiaghata Thana, Khulna District," Korea, vol. 2, no. 1, pp. 5-9, 2011.

[26] J. James and M. Versteeg, "Mobile phones in Africa: how much do we really know?" Social Indicators Research, vol. 84, no. 1, pp. 117-126, 2007.

[27] G. Demombynes and A. Thegeya, Kenya's Mobile Revolution and the Promise of Mobile Savings Policy Research Working Papers, The World Bank, Washington, D.C., USA, 2012.

[28] J. Squillace and B. Cavanagh, "Digital practitioners? Analyzing technology use among social work students," International Journal of Education and Social Science, vol. 2, no. 7, pp. 17-28, 2015.

[29] N. Selwyn, "Schooling the mobile generation: the future for schools in the mobile-networked society," British Journal of Sociology of Education, vol. 24, no. 2, pp. 131-144, 2003.

[30] R. Thackeray and M. Hunter, "Empowering youth: use of technology in advocacy to affect social change," Journal of Computer-Mediated Communication, vol. 15, no. 4, pp. 575591, 2010.

[31] M. M. Chow, "Conceptual paper: factors affecting the demand of smartphone among young adult," International Journal on Social Science, Economics and Art, vol. 2, no. 2, pp. 44-49, 2012.

[32] M. Sánchez-Martínez and A. Otero, "Factors associated with cell phone use in adolescents in the community of madrid (Spain)," CyberPsychology \& Behavior, vol. 12, no. 2, pp. 131-137, 2009. 
[33] A. Addo, "The adoption of mobile phone: how has it changed us socially?," Issues in Business Management and Economics, vol. 1, no. 3, pp. 47-60, 2013.

[34] R. S. Cobcroft, J. S. Towers, and A. Bruns, "Mobile learning in review: opportunities and challenges for learners, teachers, and institutions," in Proceedings Online Learning and Teaching (OLT) Conference 2006, Brisbane, Australia, September 2006.

[35] N. S. Baron and E. M. Campbell, "Gender and mobile phones in cross-national context," Language Sciences, vol. 34, no. 1, pp. 13-27, 2012.

[36] D. E. Madell and S. J. Muncer, "Control over social interactions: an important reason for young people's use of the Internet and mobile phones for communication?," CyberPsychology \& Behavior, vol. 10, no. 1, pp. 137-140, 2007.

[37] J. P. Rossing, M. Willie, A. K. Cecil, and S. E. Stamper, "iLearning: the future of higher education? student perceptions on learning with mobile tablets," Journal of the Scholarship of Teaching and Learning, vol. 12, no. 2, pp. 1-26, 2012.

[38] M. Hakoama and S. Hakoyama, "The impact of cell phone use on social networking and development among college students," The American Association of Behavioral and Social Sciences Journal, vol. 15, p. 20, 2011.

[39] A. D. Alanazi, The use of the smartphones as a resource for news among saudi arabian students in the united states, Ph.D. thesis, Indiana University of Pennsylvania, Indiana, PA, USA, 2014.

[40] J. Gikas and M. M. Grant, "Mobile computing devices in higher education: student perspectives on learning with cellphones, smartphones \& social media," The Internet and Higher Education, vol. 19, pp. 18-26, 2013.

[41] S. Misra, L. Cheng, J. Genevie, and M. Yuan, "The iPhone effect," Environment and Behavior, vol. 48, no. 2, pp. 275-298, 2016.

[42] M. Tehsin, A. A. Khan, and S. Turrab-ul-Hassan, "CPEC and sustainable economic growth for Pakistan," Pakistan Vision, vol. 18, no. 2, pp. 102-118, 2017.

[43] M. Z. U. Khan and M. M. Khan, "China-Pakistan economic corridor: opportunities and challenges," Strategic Studies, vol. 39, no. 2, p. 65, 2019.

[44] W. Ali, L. Gang, and M. Raza, "China-Pakistan economic corridor: current developments and future prospect for regional integration," International Journal of Research (IJR), vol. 3, no. 10, p. 210, 2016.

[45] H. U. Khan, "Regional security threats to CPEC: a strategic overview," Journal of the Research Society of Pakistan, vol. 56, 2019.

[46] U. Javaid, "Assessing CPEC: potential threats and prospects," Journal of the Research Society of Pakistan, vol. 53, no. 2, 2016.

[47] M. F. Sultan, "Analyzing prevalent internal challenges to china pakistan economic corridor (cpec) through public opinion," Journal of Economics and Sustainable Development, vol. 10, no. 7, 2019.

[48] Z. Latif, Z. Jianqiu, R. Ullah, Z. H. Pathan, and S. Latif, "Application of optical frequency comb in high-capacity long distance optical communication for China-Pakistan economic corridor," Journal of Optical Communications, vol. 38, pp. 331-340, 2017.

[49] Web Access, 2019, https://www.thequint.com/news/hot-news/ india-snubbed-pak-china-initiate-cpec-project-in-gilgit-baltistan.

[50] Y. Hao, K. S. Lee, S.-T. Chen, and S. C. Sim, "An evaluative study of a mobile application for middle school students struggling with English vocabulary learning," Computers in Human Behavior, vol. 95, pp. 208-216, 2019.
[51] A. Risquez, C. McAvinia, R. Damien et al., "An investigation of students' experiences of using virtual learning environments: implications for academic professional development," in Emerging Issues in Higher Education 111: From Capacity Building to Sustainability, pp. 99-112, Educational Developers in Ireland Network (EDIN), Belfast, Northern Ireland, 2013.

[52] M. Alrasheedi and L. F. Capretz, "Determination of critical success factors affecting mobile learning: a meta-analysis approach,” 2018, https://arxiv.org/abs/1801.04288.

[53] D. Raftery, "Ubiquitous mobile use: student perspectives on using the VLE on their phone," Irish Journal of Technology Enhanced Learning, vol. 3, no. 2, pp. 47-57, 2018.

[54] K. Burden, M. Kearney, S. Schuck, and T. Hall, "Investigating the use of innovative mobile pedagogies for school-aged students: a systematic literature review," Computers \& Education, vol. 138, pp. 83-100, 2019.

[55] M. Adnan and B. Giridharan, "Use of social media applications in classroom: analysis from education perspective," IOP Conference Series: Materials Science and Engineering, vol. 495, Article ID 012108, 2019.

[56] L. F. Motiwalla, "Mobile learning: a framework and evaluation," Computers \& Education, vol. 49, no. 3, pp. 581-596, 2007.

[57] C. Kaatz, C. Brock, and L. Figura, "Are you still online or are you already mobile? - predicting the path to successful conversions across different devices," Journal of Retailing and Consumer Services, vol. 50, pp. 10-21, 2019.

[58] S. A. Becker, NMC Horizon Report: 2017 Higher Education Edition, The New Media Consortium, Austin, TX, USA, 2017.

[59] P. K. Smith, J. Mahdavi, M. Carvalho, S. Fisher, S. Russell, and N. Tippett, "Cyberbullying: its nature and impact in secondary school pupils," Journal of Child Psychology and Psychiatry, vol. 49, pp. 376-385, 200. 